\title{
HENRY JAMES BAKER
}

ThE announcement of the death of Henry James Baker which occurred at Bournemouth on 18 November 1948 at the age of 75 revives recollections of one who was for many years closely associated with the work of the Institute but who, since his retirement from official life twenty years ago, had been unable to continue most of those activities. For some years past he had not enjoyed good health and, apart from that, his residence in Bournemouth made it difficult for him to undertake many engagements in London. Consequently he was little known to the rising generation of actuaries.

The following record is testimony to his work for the Institute. He served on the Council for 15 years, was Examiner 9 times, Honorary Secretary $192 \mathrm{I}-22$ and Vice-President 1923-26. He also, jointly with A. H. Raisin, compiled and published extensive tables based on the British Offices $\mathrm{O}^{[\mathrm{MI}}$ and $\mathrm{O}^{[\mathrm{NN}]}$ Tables.

Baker was an extremely rapid and accurate calculator and was responsible for the supervision of the monetary tables issued by the Joint Committee for the I 863-93 experience. Baker and Raisin's tables were finally incorporated in the full issue of the official tables in 1907 .

Baker's insurance career started at the North British and Mercantile office, under H. J. Cockburn, sixty years ago. After eight years, he obtained his Fellowship and then joined the Metropolitan as an actuarial assistant. He subsequently became Actuary and, in ror 8 , Chief Officer of that Society. This position he held until the Society amalgamated with the London Life ten years later. Although then only 55 years of age, he retired from active official life, but maintained his association with his old office as Consulting Actuary to the Metropolitan Fund. Retirement, however, did not mean for him that his actuarial work was finished, as he continued a considerable private practice. In his earlier days, Baker was associated with George King in much of the latter's consulting work and, on George King's retirement, Baker succeeded to a good deal of this work, which consisted mainly in the valuation of large pension funds.

Naturally a very conscientious worker, he brought to any problem with which he had to deal unstinted application and effort. For him, no trouble was too great which would help in the production of reliable results.

Baker was elected a member of the Actuaries Club in 1914 and acted as Treasurer of that Club from 1918 to 1924 . I believe his only outdoor recreation was golf. He was a member of Bushey Club until his retirement to Bournemouth when he joined Parkstone Club.

It is difficult to convey any very clear description of Baker's personal characteristics. His was a somewhat reserved disposition and possibly, to many who were not intimately associated with him, this gave the impression that he was rather cold and formal in manner. Closer acquaintance with him, however, revealed that he had a kindly and sympathetic nature, qualities which his old friends will have pleasure in remembering.

A. T. W. 